This is an electronic reprint of the original article. This reprint may differ from the original in pagination and typographic detail.

Author(s): Nokkala, Terhi

Title: Making the case for policy : persuasiveness in higher education, science and technology policy discourse

Year: $\quad 2016$

Version:

Please cite the original version:

Nokkala, T. (2016). Making the case for policy : persuasiveness in higher education, science and technology policy discourse. European Journal of Higher Education, 6(2), 144-158. https://doi.org/10.1080/21568235.2015.1086664

All material supplied via JYX is protected by copyright and other intellectual property rights, and duplication or sale of all or part of any of the repository collections is not permitted, except that material may be duplicated by you for your research use or educational purposes in electronic or print form. You must obtain permission for any other use. Electronic or print copies may not be offered, whether for sale or otherwise to anyone who is not an authorised user. 


\title{
Making the Case for Policy \\ - Persuasiveness in Higher Education, Science and Technology Policy Discourse
}

\author{
Terhi Nokkala \\ University of Jyvaskyla*), Finnish Institute for Educational research \\ P.O. Box 35 \\ FI-40014 \\ University of Jyvaskyla \\ Finland \\ *) for technical/conversional reasons letter ä is replaced with letter a
}

\begin{abstract}
Policy texts present problems, propose solutions to those problems and persuade multiple audiences of the legitimacy of the proposed problems and solutions. The rhetorical analysis of two decades of higher education and science and technology discourse in Finland, Germany, United Kingdom, Portugal and United States highlights the discursive elements that contribute to persuasiveness of policy, construe it as rational and logical, and create a sense of urgency in bringing it about. I argue that the analytical and hortatory registers of policy discourse foreground competitive and hierarchical relations of countries and their higher education systems. By construing certain state of affairs and courses of action as selfevidently desirable and true, they contribute to the emergence and reproduction of the neoliberal political rationality proposed by the Foucauldian governmentality theory.
\end{abstract}

Keywords: policy discourse, persuasiveness, higher education policy, science and technology policy, governmentality

\section{Introduction}

The task of policy is to foreground problems; propose solutions to those problems and persuade its audiences - politicians, voters, tax-payers, civil society, labour market actors etc., depending on the given political system - of the legitimacy of the proposed problems and solutions (Schmidt 2002; Sell and Prakash 2004).

Individual policies are communicated as semiotic instances through policy documents that are written to specifically argue for a certain point, aimed at multiple audiences to persuade various actors to act in a way that the policy goal can be reached. This persuasive function of 
policy sparks interest for the strategies that are adopted to represent and frame the presented policy problem and its advocated solution.

As Suspitsyna (2010, following Edwards and Nicoll 2001) notes, "Far from being a simple act of spin-doctoring, policy rhetoric relies on legitimate tools of persuasion to make some constructions of reality more appealing than others" (Suspitsyna 2010, 38). Individual policies as semiotic instances ${ }^{1}$ are thus imaginaries, which construct particular versions of reality and suggest particular courses of action. The question this paper sets out to answer is: what kinds of discursive elements are used in policy texts to make policy persuasive, construe it as rational and logical, and create a sense of urgency in bringing it about. I argue that policy discourse foregrounds competitive and hierarchical relations of countries and their higher education systems. By construing certain state of affairs and courses of action as selfevidently desirable and true, they contribute to the emergence and reproduction of the neoliberal political rationality proposed by the Foucauldian governmentality theory.

In the following, I will first highlight the use of linguistic analyses in the study of Foucauldian government, followed by the description of the data and the analysis method used in this study. Second, I will analyse the discursive elements in policy texts used to make the policy discourse in the higher education and science and technology policies in Finland, United Kingdom, Germany, Portugal and United States/California persuasive. Finally, I will conclude with a discussion on how persuasive policy texts contribute to governing the objects of policy, namely organisations and individuals. The questions on the impact of policy discourse fall outside the scope of this article. However, as Schmidt (2002) has shown, the government's ability to back up cognitive arguments, such as the economic rationales for policy change with normative, legitimating discourse; has been a significant factor in contributing to the success of the proposed policy reforms. Schmidt points out that the audiences of policy discourse, as well as whether the discourse aims primarily at coordinating the aims of a policy reform amongst key policy groups or communicating its necessity to wider public, vary between countries and depend on the openness of their political system.

\section{Linguistic Approaches to studying Foucauldian Government}

In the Foucauldian tradition (Burchell et al 1991; Burchell 1993; Rose and Miller 1992; Gordon 1991) the concept of 'government' is used to refer to a way of acting on the actions of others either as individuals or collectives in order to shape and modify the ways in which they conduct themselves; and to the various 'technologies' for coaxing and training individuals to behave in a desired way. The Foucaultian tradition(Burchell et al 1991) argues that the current logic according to which the society functions, its governmental rationality or 'governmentality', is that of advanced liberalism or neoliberalism. In advanced liberalism, the notions of entrepreneurialism, enterprise culture and 'knowledge society' create a totalising and unifying meta-narrative (c.f. Jessop 2004). According to the knowledge society metanarrative, economic growth and development are based on science, education and

\footnotetext{
${ }^{1}$ I use the concept of semiotic instance to distinguish the 'meaning-making, -carrying and -interpreting' elements of policy from the notion of policies as implemented or internalized practices.
} 
technology. The meta-narrative emphasises efficiency, effectiveness, excellence, information revolution, performance and enterprise talk which penetrate all fields. (Peters 1996, 88-8; Trowler 2001.) Governing of the subjects of knowledge society takes place through a process of translation, whereby individuals, or organisations, come to see their personal objectives in line with those of the relevant authorities. Similarly, various processes of discursive persuasion and negotiation lead to constructing common views of the nature of reality and appropriate action. (Rose and Miller 1992, 184). Organisations, as well as individuals appear to make free choices, but the powerful rationality of the knowledge society as it is played out in the discourses, guides their activities.

Many linguistic or discursive approaches have been applied to study how policies contribute to the triumph of the 'neoliberal' (Larner 2000) or 'advanced liberal' (Rose and Miller 1992) governmentality. Susan Robertson's (2005) work focuses on the role of the discourse of the global organisations such as the World Bank and the OECD in advocating new understandings of learning and education in a (competitive) knowledge society. Suspitsyna's (2010, 2012) study uses rhetorical analysis to study the construction of neoliberal governmentality through the rhetoric of accountability, economic advancement and engaged citizenship in US higher education discourse. She notes, for example, that the discourse of the US Department of Education co-opts the different functions of higher education, such as the economic advancement and active citizenship, so that the latter can be re-signified to be part of, and contribute to the former (Suspitsyna 2012). Similar mechanism of the co-optation of discourse is noted in Nokkala and Bacevic's (2014) discourse-historical analysis, which notes the neoliberal discursive shift of the notion of university autonomy as part of the efforts of the European University Association to legitimize itself as an agent in the European Higher Education Area. Similarly, Nicoll and Edwards (2004) study the rhetoric of lifelong learning (LLL) in UK policy discourse, and argue that the LLL discourse is applied as a technology of neoliberal government aimed at subtly steering individuals and populations to act in desired ways; while Davies and Bansel (2010) use a Foucauldian discourse analysis to study the audit culture as an example of a technology of government working upon the subjectivities of academics in Australia. Muntigl (2002) uses the genre and register theory from systemic functional linguistics to study how European employment policy legitimizes the neoliberal view on employment. Mulderrig's (2011) corpus-based critical discourse analysis highlights, from a historical perspective, the development of the construal of the roles and responsibilities of the various actors in the education discourse of the New Labour, and argues for it to be the key component of the "enabling” governance that was part of the social project of the New Labour. Nokkala's discourse analysis (2007) highlights how internationalization of higher education discourse is used to obligate nation states, universities and individuals alike to "internationalise”, “open up”, and "rethink their activities". Finally, Elias uses (2013) critical frame analysis to investigate the construction of neoliberal female subjectivities in the context of the World Economic Forum (WEF). Whilst much of this work focus on textual forms of semiosis, Elias's analysis encompasses also an analysis of how non-textual structures, such as the presence of women in the WEF contribute to the representations of gender in the context of WEF. 


\section{Analysing European HE/ST Policy}

This paper draws from a larger international comparative study analysing the overarching knowledge society discourse, its most significant national variations and persuasive discursive features in the higher education and science and technology policy in Finland, UK, Germany, Portugal and United States (Federal level and California) from late1980's to 2010 (Nokkala Forthcoming 2015). Though the inclusion of various supranational actors, such as EU, OECD, World Bank or UNESCO into the analysis could convincingly be argued (e.g. Vaira 2004), they were left out for the sake of research-economic prudence. Following Saarinen (2008), I make a distinction between three concepts: documents, text and discourse. Documents refer to material artefacts, originally produced on paper but nowadays increasingly existing in electronic format. The data for this study comprised sixty policy documents $^{2}$ amounting to more than 4000 printed pages, originating from five countries, and written over approximately two decades from 1990 to 2010. The document lengths varied from merely dozen pages to hundreds of pages. Most of the documents were electronic, but ca. $20 \%$ of the (older) documents were accessible only as paper copies. Text or policy text refers to the excerpts from those documents that carry the contents and meanings of policy. Discourse refers to a "system of statements which construct an object; they are social practices which mould the social reality" (Nokkala 2007, 95). Specifically the word is used here to refer to a way of speaking or writing which "gives meaning to experiences from a particular perspective and can be distinguished from other discourses". (Nokkala 2007, 95). Finally, I use the concept of discursive elements to denote the various large scale semiotic ${ }^{3}$ structures and overall organization of policy texts that are used to make the policy text persuasive.

My analysis process focused on the identification of the content themes and large scale discursive elements in the policy texts rather than on the fine grain grammatical analysis of individual sentences (c.f. Halliday and Matthiesen 2014). I analysed the data in successive rounds of close reading of the documents, paying attention on the one hand to the stories told by the texts about what knowledge society is like, in general as well as in particular countries, and on the other hand to the discursive elements and structures that were used to tell those stories ${ }^{4}$. After an initial reading of the documents to identify the relevant passages and themes from the massive amount of text, I noted down the content themes, and the prominent or extraordinary lexical choices that immediately caught my attention. This provided me a good overview of the entire data set, and it was possible to see features and structures in the texts that are repeated and reproduced over the broad spectrum of the data, across countries and decades, and see whether particular features seemed to relate primarily to the content and direction of the policy in the higher education in the different countries (see Nokkala

\footnotetext{
2 The full list is presented in Nokkala Forthcoming 2015; here I have listed only the ones explicitly quoted in the text.

3 These are mainly textual elements, but can also be numerical or e.g. visual. I have paid attention to numerical representation in the form of statistics but not to the visual elements, e.g. images.

4 The general and national stories about Knowledge Society and higher education have been reported in Nokkala Forthcoming 2015.
} 
Forthcoming 2015), or to the discursive elements related to making a convincing case for that policy. In the second round of analysis, I produced a lengthy description, amounting to more than 100 pages of text, summarising and paraphrasing the key themes and the ways they were presented in the policy texts. In this summary I paid special attention to those discursive elements of the policy texts that were used to legitimate the policy, construe it as rational and logical, and create a sense of urgency in bringing it about. In the next stage, the elements were systematized and again reworded, and grouped into the categories described below. In the final stage of analysis I adapted the concepts of genre and registers to make sense of these discursive elements and understand what exactly it was that was making policy texts persuasive or convincing.

Genres can be defined as the usage of language related to particular social practices, such as media, academia or policy-making. The different genres related to media as a social practice, would include, for example, the news genre and the advertising genre (Jørgensen and Phillips 2002, 67); and the genres of academia would include, for example, the scholarly writing genre or pedagogical instruction genre. The genres of policy-making, such as the policy documents or political speeches, are persuasive, and comprise statements that function either to persuade others to adopt a certain view of the world (persuade that) or to act in a particular way (persuade to) (Muntigl 2002).

In the following, I use the word 'register' to denote these shifts in the goal of the texts (Muntigl 2002; Birch and O’Toole 1988, 11, cited in Leckie-Tarry 1995, 13): I thus argue that the policy texts use two registers: to argue for the way the world is or to argue for a certain course of action.

I adapt Martin's (1989, 16-17; see also Muntigl 2002) notions of hortatory and analytical exposition to describe these two registers: The register for analytical exposition (the analytical register), refers to the discursive elements that tell what the world is like. The analytical register describes the state of the art of a policy question (virtues and failings), sets it in context by illuminating it in an international or chronological context, describes the direction of the change for the country in that policy question, and vis-a-vis other countries; and finally, makes the emotive case for changing the state of the art. The register for hortatory exposition, (the hortatory register), refers to the discursive elements that tell what should be done and how it should be conducted in order to achieve the (desired) state of affairs. It describes the preferred way people and organisations should go about their business, persuades them to accept targets and standards that define the desired state of affairs; defines the intensity and direction of change to achieve the desired state of affairs; and finally presents these as a taken for granted so that no alternative can be conceived for them.

\section{Making the Case - the Two Registers in European HE/ST Policy}

\subsection{The Analytical Register}

The analytical register of the European higher education and science and technology policy texts describes the state of affairs, constructs the 'facts' and gives them a positive or a 
negative connotation. I illustrate three types of discursive elements (although others may exist as well) comprising the analytical register, i.e. elements that pertain to the particular way of speaking about higher education, science and technology and issues related to them. These include framing of policy through virtues and failings, national longitudinal and international comparative statistics used to organize the hierarchical relations between countries or along a historical continuum; and the developmental dynamics which construe a normative evaluation of this hierarchy.

\subsubsection{Framing of Policy through Virtues and Failings}

The framing of policy through virtues and failings is typically used in policy documents to legitimate the advocated policy. First the country's virtues are extolled: the country is described as excelling in some policy field with high quality, excellent infrastructures and outstanding results; followed immediately by listing its failings and problems, and arguing that the country is feared to be falling or lagging behind (see 4.1.3) its competitors on many important aspects. The remainder of the policy document typically explains the planned action for remedying the problem. The framing forms the justification for change and creates a sense of urgency in the discourse. The failings and problems are typically highlighted in relation to a preferred state of affairs. This preferred state of affairs may be represented by another country/countries (as evidenced by comparative international statistics, see 4.1.2); targets set in policy (see 4.2.2), or just in relation to unspecified or specified change or external challenges such as demographics, advances in technology, importance of knowledge, or globalisation (see 4.2.3).

The framing of policy through virtues and failings is, for example, illustrated in the following excerpt from Finland's Science and Technology Policy Council's report from 2008, which first outlines Finland's successes in terms of society, education and economy; then goes on to argue that despite all the successes, Finland is not sufficiently attractive as a country.

"Finland has succeeded in maintaining close interactive connections between positive economic development, the multi-faceted development of society and the increase in well-being. This has been helped by the high educational level of the population, as well as the wide-ranging utilisation of knowledge and know-how. The development of the economy and employment has been favourable in the 2000s: our GDP has grown faster than the EU and the Euro area average. GDP per capita in Purchasing Power Standards has remained 15\% above the EU and 5\% above the Euro area average.[...] Despite competence and top-level innovation environments, Finland's attractiveness as an investment target for industrial production and high technology, as well as a working environment for top experts, is not sufficient." (FI23, 2008, 9, 13)

Most explicit this framing is in the UK (2008) excerpt, which first presents the strengths of UK in terms of research, business and economy, and then goes on to outline a number of weaknesses broadly related to the same. 
"The UK has a number of strengths: a leading position in scientific research, a number of highly competitive business sectors, a stable and supportive macroeconomic climate and flexible product and labour market regulation.

[...] However, there are a number of areas in which the UK must improve. The UK's productivity performance has been improving steadily since 1997 but still lags some leading international competitors. Moreover, there remain longstanding weaknesses in the skills base and in the number of employers investing in training”. (UK7, 2008, 3)

\subsubsection{Statistics}

Policy texts commonly make use of international comparative statistics or national longitudinal statistics to indicate the situation of the country in relation to a particular policy question.

National longitudinal statistics can, for example, be used to show progress made in terms of educational attainment, R\&D investment or knowledge intensity of the economy. National statistics are often referred to in order to indicate that the government or other authority has been a decisive actor in the given policy issue and has brought about a positive change over a given period of time.

International comparative statistics, on the other hand, are often used to indicate the relative status of the country vis-a-vis other countries which are thus constructed as competitors or as peer group which the country wants to be counted in to (Nicoll and Edwards 2004, 51-52). International statistics are used to illustrate the (urgent) need for change. The following German text combines textual description of the relative position of Germany in the described policy issues with numerical statistics (omitted here for the sake of brevity), which contain illustrations both of the relatively speaking higher and lower position of Germany vis-a-vis its competitors.

"Germany occupies a leading position in many major infrastructure areas. It appears favourably on an international comparison in the digitalisation of the telephone network, for example (Fig. 4)1).[...] Despite these considerable successes it must be said that on an international comparison Germany is still not among the leaders in many areas. The number of PC users in the United States and some Scandinavian countries has grown even more strongly than in Germany and Germany is now only in the middle field here (Fig. 5).[...] The gap between Germany and other countries, particularly the United States, in Internet and online connections has widened further, despite the strong growth here compared with the United States (Fig. 6).” (DE2, 1999, 19, 21)

Statistics are also a type of technology of government and contribute to defining what counts as societal facts (Hacking 1991, 181). In the context of higher education policy texts, the use of statistics is often, although not necessarily, related to the targetisation of policy (see 4.2.2) and part of a larger trend towards evidence-based policy (Sanderson 2002), in which statistics, surveys and evaluations are used to justify policy decisions. The concept of 
evidence-based policy is sometimes explicitly mentioned, sometimes an implicit notion. The use of international statistics and comparisons or, e.g. OECD reviews or EU policies (c.f. Dale 2006; Moisio 2014; Heitor and Horta 2014), as legitimation for policy, is an indication of the increasingly international frame of reference for education policy. International statistics are used especially in those texts that frame education or research as an activity where countries and/or organisations are in competition with each other.

\subsubsection{Developmental Dynamics}

Another discursive element that makes up the analytical register of policy, are what I call 'developmental dynamics', which are used to describe the relative position of the country visà-vis determined (or sometimes undetermined) other countries in terms of a given policy issue. They are developmental in that they the explicate the state of development of the policy issue in question; and dynamic in a sense that they indicate the direction of the development of the country vis-a-vis other countries and/or in relation to the policy issue in question. They construct a continuum of developmental stages and imply different loci and speed of development. The four developmental dynamics that I have identified in the texts are lagging behind, falling behind, catching up, and leading nation. Several of these may co-occur in a single text.

Lagging behind describes a situation where the country is either static or moving forward in terms of a given policy question but at a slower pace than its peer group or competitors. The Portuguese extract implies Portugal lagging behind its peer group, the other European countries, in terms of the number of graduates, whilst the UK excerpt is explicit about lagging behind as well as about having 'competitors' rather than a peer group.

"In fact, Portugal is one of the European countries with the lowest number of graduates and increasing the academic and professional qualifications of the Portuguese society continues to be an essential factor for its economic, social and technological modernisation.” (PT4, 2006, 182)

"But as Lord Leitch's review set out, we still have a mountain to climb. Although the UK has narrowed the productivity gap with our major competitors, we still lag behind the most successful economies. A major reason for this is weaknesses in our skills base. More than a third of all adults in the UK don't have the equivalent of a basic school leaving certificate. 6.8 million people have serious problems with numbers, and 5 million people aren't functionally literate." (UK6, 2007, 6-7)

Falling behind describes a situation where the country is possibly at par or behind its competitors but the direction of development is backwards. In the German excerpt, the phrase 'could deteriorate in the future' indicates a backward dynamic although the rest of the excerpt could be interpreted also as lagging behind.

“Germany's successes in worldwide innovation competition are based primarily on a good education and training for our personnel. However, the high level of 
skills could deteriorate in future if steps are not taken to prevent this. In Germany only $16 \%$ of school-leavers complete a university course; that is not enough for a modern industrial nation like ours, if the OECD average is $25 \%$." (DE6, 2002, 7-8, emphasis in original)

Catching up dynamic indicates a situation where the country is behind its competitors but shows a clear forward trend. The German excerpt is aspirational and the catching up dynamic is explicit: Germany wants to catch up with its competitors in terms of attractiveness to foreign students and staff.

"Teaching, learning and conducting research beyond national borders are increasingly being taken for granted. Nevertheless, Germany has a lot of catching up to do. The country must succeed in attracting more foreign students to Germany, and it must get more foreign researchers interested in doing research in Germany. To this end, it will be necessary to offer new and more attractive conditions" (DE3, 2000, 17)

The fourth dynamic, Leading nation, implies a situation where the the status of the issue at hand may be stable or moving forward and the country is in a leadership position in relation to other countries. In the excerpt from a UK policy document, the leadership position is indicated by expressions such as 'the best' and 'world class' whilst 'dramatic increase' indicates the direction of the change.

"We can be proud of our universities. The number gaining degrees has tripled in the last two decades while safeguarding quality. Completion rates for students are among the best in the world. More overseas students are studying here. Our research capacity is strong and, at best, world class. Recent years have seen a dramatic increase in the number of new companies spun out of universities' innovation." (UK3, 2003, 4)

The developmental dynamics are often accompanied with international comparative statistics, which are used to legitimise the claim that a given country is lagging behind, falling behind, catching up or being/aspiring to be a leading nation in terms of a given policy question.

Occasionally they are, however, used merely as a rhetorical device, without any evidence to back them up. Especially those developmental dynamics with a negative connotation, lagging behind and falling behind, are used to convey a sense of urgency for adopting the proposed policy change.

\subsection{The Hortatory Register}

The hortatory register of policy indicates how things should be (done), it instructs organisations or individuals to act and behave so that the state of affairs described in the analytical register can be changed, or the desired state of affairs achieved. In the following I will illustrate the realization of the hortatory register through three discursive elements: preferred modes of doing things, which pertains not to what should be done, but to how it should be done; construction of power dynamics through targets, indicators and standards; 
and finally the discourse of change, its causes, consequences and continuously moving goal posts, which I call the Red Queen discourse (c.f. Easton 2007).

\subsubsection{Modes of action}

The policy discourse features elements which pertain to the mode of action, or "ways of doing things", i.e. to the ways on which the action of organisations or individuals is to be carried out. Particular modes of action are presented as desirable or preferable, and here I wish to highlight two of these; doing things effectively and efficiently on one hand and doing things in collaboration with others on the other hand.

Effectiveness and efficiency are words which regularly appear in policy texts and connote such preferred mode of action. Efficiency and effectiveness in policy texts may refer to the activities of higher education institutions, policy makers, individuals etc. As modes of action they may be directed at the higher education institutions as objects of government, or to the governing institutions themselves. In the Californian text below, the demand for efficiency and effectiveness is both directed at "California" and "public institutions". We may even speculate whether the former, in this case, in fact stands for the latter.

"If instructional quality and responsiveness to diversity are to be ensured in the future, California must be certain that it is now making effective and efficient use of all of its postsecondary education resources, public and private. In an era of rapidly rising costs for other public services and growing constraints on state revenues, efficiency in the operation of the public institutions is essential if there is to be adequate funding for further growth." (US/CA1, 1987, 39)

Another mode of action prioritised in the policy texts is the notion of collaboration (sometimes also 'cooperation', 'networking' and 'partnerships' are used), which is evoked as a means to increase efficiency and effectiveness, quality, or relevance. Collaboration may refer to collaboration between higher education institutions (or other knowledge producing units), or with industry/business/employers. It may also refer to collaboration between policy makers or authorities at different levels of administration. It may refer to collaboration regionally, nationally or internationally. In the following excerpt from Finland 'cooperation' and 'networks' are credited with 'leading to success' whilst 'educational sector' is argued not to have adopted and developed a cooperative culture; the connotation of this latter sentence is in this context a negative one. The Portuguese excerpt, while containing a similar implicit message about the beneficiality of networking and collaboration, operationalises them as 'interactions' and presents a presupposition of this beneficiality of being generally known.

"The key issues of the information society are cooperation and networking. The major factors leading to the success of an expert organisation are the ability to network and interact. Nevertheless, the adoption and development of a cooperative and networking operational culture and the utilisation of technological progress are not established practices in the educational sector." (FI9, 2000, 45) 
"As far as science, innovation and the dissemination of knowledge is concerned, it is well known that interaction between the agents involved enhances the generating capacity and the quality of results, and consequently social benefits exceed private ones”. (PT4, 2006, 44)

\subsubsection{Targetisation of policy: targets, indicators and standards}

Indicators, targets and standards of performance of higher education and research system started to abound in the policy documents especially during the 2000s. This phenomenon can be summarised as ‘targetisation of policy’ (c.f. King 2014: 160; Jansen 2005) . Setting descriptive or numerical targets, and indicators for meeting those targets, serves to order the political domain, and construct the power relations between those who set the targets and those whose task it is to reach them. Targets, indicators and standards are often combined with the notions of efficiency and effectiveness as desired modes of action or 'ways of doing things' (see 4.2.1), or with national longitudinal statistics or comparative international statistics (4.1.2).

The following excerpt from the US Department for Education strategic plan 1998-2002, for example firstly determines skills in terms of earning power, then implicitly obligating the addressees, 'adults', to engage in lifelong learning, and even more implicitly obligating the educational institutions and public bodies responsible for the administration of such instruments as 'Lifetime Learning tax credit'.

"Objective 3.4: Adults can strengthen their skills and improve their earning power over their lifetime through lifelong learning.

Performance Indicators

19. The percentage of persons who are aware of and use the Lifetime Learning tax credit will increase annually.

20. The percentage of persons who maintain competitive employment and earnings 24 months after completion of vocational rehabilitation will increase significantly by 2002.[...]"(US1, 1998,41)

Standards similarly construct and communicate power structure. Standards stand in for quality and objectivity and function to obligate organisation, such as higher education institutions, but also individuals, such as teachers to act in a particular way sanctioned by the description of the standards (Nicoll and Harrison 2003). Whilst they appear to empower an individual, such as a student or learner, they also imply a narrow understanding of the quality of education. The following text, illustrating the setting of standards in a policy, frames good education mainly in terms of achieving standards and then sets the particular organisations as gatekeepers of those standards, whilst obligating teachers, higher education institutions and individual courses to fulfil them.

"In order that teaching in higher education is treated seriously as a profession in its own right, and that teachers are given the skills they need, we expect that national 
professional standards will be agreed by 2004-05, through the proposed new teaching quality academy, described below. These standards, to be designed and agreed by the sector itself, would then describe competences required for all teaching staff. [...] QAA has performed an important role in assuring academic quality and standards in higher education. [...] Recently, the QAA external review processes were radically changed to reduce the burden on higher education institutions, recognising the progress that has been made. The new model firmly places the responsibilities on institutions themselves to have robust internal systems for assuring quality and standards systems.[...] External examiners carry out a critical role in advising institutions on the comparability of their standards, and in many respects act as guardians of the public purse and of the reputation of $U K$ higher education”. (UK3, 2003, 49-50)

\subsubsection{Change and the Red Queen -discourse}

Characteristic of the higher education and science and policy discourse in all of the studied countries is the notion of change (see Saarinen and Välimaa 2012). Typical of the description of change is, that an already happened or happening change in external factors, society or operational context is argued to necessitate change in the object of policy, or the entire policy itself. For example, the notion that society, the labour market, demographics or international interconnectedness have changed; is used as a justification for the need to change education and skills structures. Sometimes the source of the change is mentioned, often only vague mentions to 'knowledge society' or 'new age' are made.

"We are in a new age - the age of information and of global competition. Familiar certainties and old ways of doing things are disappearing. The types of jobs we do have changed as have the industries in which we work and the skills they need. At the same time, new opportunities are opening up as we see the potential of new technologies to change our lives for the better. We have no choice but to prepare for this new age in which the key to success will be the continuous education and development of the human mind and imagination." (UK2, 1998, section 1)

A typical example of the change discourse is a narrative where the development of information and communication technologies (ICTs) is the source of change: ICTs are changing the world of work; they increase the quality of life, and enable the empowerment of individuals and active citizenship. New skills are required of individuals both for work and for personal empowerment, which in turn requires change in education and institutions, including curriculum and teaching methods, as well as libraries and educational ICTinfrastructures. Updating skills throughout life becomes important (Nokkala Forthcoming 2015).

"The rapid development of the information society both requires and facilitates an increase in the knowledge level of the nation as a whole. [...]From the 
viewpoint of working life and citizens' society it is necessary to steer educational input increasingly to the adult population and to build the support structures of educational provision and learning to extend throughout life. [...]Because of the rapid development, lifelong learning is an essential element of the new strategy". (FI9, 2000, section 2.2.1)

The notion of change is often combined with the Red Queen-discourse, evoking the famous notion of running faster to stand still, from Lewis Carroll's Alice Through the Looking Glass (c.f. Easton 2007), and linked also to the falling behind -dynamic. An example of this is the Finnish discourse from the early 1990s, of doing more things with same or smaller amount of money more efficiently, faster and with higher quality (Nokkala Forthcoming 2015). The German excerpt calls for “joint efforts” by “politicians, employers and unions”.

"Germany must make better use of its knowledge - for new products, new services and new opportunities on growing markets. The conditions are good. Now joint efforts by politicians, employers and unions are needed to gather our forces and set the necessary actions in motion. [...] No country can take it for granted that it can keep the position it gained in income and employment in the industrial age in the information age. Knowledge and innovative ability are the decisive production factors now. To utilise these to create new scope for employment is the central task for the 21st century." (DE2, 1999, 6)

5 Discussions and Conclusions All the aforementioned elements contribute to a notion that 'there is no alternative ${ }^{5}$ to the presented policy, which appear as the only rational and logical course of action. Presenting a policy as having no alternative spares the presenter from making a convincing argument for it, and thus helps avoid a situation where the argument would come under scrutiny and possibly be overturned (c.f. Saarinen 2008). This contributes to the emergence of hegemonic discourses and meta-narratives, such as the knowledge society to which no alternative can be conceived.

While the higher education and science and technology policy discourse in the analysed countries both reproduce the hegemonic meta-narrative of knowledge society and translate it to their specific contexts and needs (Nokkala forthcoming 2015); the registers used to realise the persuasiveness of policy are remarkably consistent, with only slight variation in intensity or application over time and across borders. The analytical and hortatory registers serve to construct the credibility of the proposed policies, to create urgency for change and to assign the hierarchies of actors, higher education and innovation systems and ultimately the nation states they represent vis-a-vis other actors, systems and states. At the same time, they are largely silent on alternative courses of action, implicitly foregrounding a competitive and hierarchical view of the relationships of countries and their higher education and science and technology systems. The persuasiveness of policy functions, in the end, as more than a mere

\footnotetext{
${ }^{5}$ I am aware of the Thatcherian connotation here, see also Fairclough, (2000, viii).
} 
rhetoric. By construing certain states of affairs and relationship between countries, and in relation to higher education and science and technology policy themes as self-evidently more desirable than others, they propose logical courses of action for the stakeholders of policy. Thus they contribute to the emergence and reproduction of the 'advanced liberal' or 'neoliberal' political rationality proposed by the Foucaultian governmentality theory.

\section{Notes on contributor}

Dr Terhi Nokkala is a Senior Researcher at the Finnish Institute for Educational Research (FIER), University of Jyväskylä. Her research focuses on the interplay between higher education policy, technological developments, organisational parameters and networks, and individual experiences in various aspects of higher education, with specific interest in internationalisation, research collaboration, academic careers and university autonomy.

\section{References}

Birch, D., and M. O’Toole. 1988. "The power of functional stylistics”. In Birch, D., and M. O’Toole, eds. 1988. Functions of style. London: Pinter Pub Limited.

Burchell, G. 1993. "Liberal government and techniques of the self." Economy and society, 22(3): 267-282.

Burchell, G; C. Gordon, and P. Miller, eds. 1991. The Foucault effect: Studies in governmentality. London: Harvester Wheatsheaf.

Dale, R. (2006). "Policy relationships between supranational and national scales: Imposition/resistance or parallel universes”. In: Kallo J. and R. Rinne eds. 1991. Supranational regimes and national education policies encountering challenges, 27-49. Turku: Finnish Educational Research Association.

Davies, B., and P. Bansel. (2010). Governmentality and academic work: shaping the hearts and minds of academic workers. Journal of Curriculum Theorizing, 26(3).

http://journal.jctonline.org/index.php/jct/article/view/250/85

Easton, P. 2007. "Adult Education and Social Sustainability: Harnessing the" Red Queen Effect".” Convergence, 40(1-2), 171-185.

http://web.a.ebscohost.com/ehost/pdfviewer/pdfviewer?vid=2\&sid=108d9636-c4f6-4d5fa892-d47cee706835\%40sessionmgr4005\&hid=4207

Edwards, R. and K. Nicoll. 2001. "Researching the rhetoric of lifelong learning.” Journal of Education Policy, 16(2): 103-112. doi: 10.1080/02680930010025310

Elias, J. 2013. "Davos Woman to the Rescue of Global Capitalism: Postfeminist Politics and Competitiveness Promotion at the World Economic Forum”. International Political Sociology, 7(2): 152-169. doi: 10.1111/ips.12015 
Fairclough, N. 2000. New Labour, new language?. London: Routledge.

Gordon, C. 1991. “Governmental rationality: an introduction.” In: Foucault, M., G. Burchell, C. Gordon, and P. Miller, eds. 1991. The Foucault effect: Studies in governmentality. London: Harvester Wheatsheaf.

Hacking, I. 1991. "How should we do the history of statistics? In: Burchell, G.' Gordon, C. and P. Miller, eds. 1991. The Foucault Effect. Studies in Governmentality, 181-195. London: Harvester Wheatsheaf.

Halliday, M. and C. Matthiessen. 2014. An introduction to functional grammar. $3^{\text {rd }}$ ed. Abingdon: Routledge.

Heitor, M., and H. Horta 2014. Democratizing Higher Education and Access to Science: The Portuguese Reform 2006-2010. Higher Education Policy, 27(2), 239-257. doi:10.1057/hep.2013.21

Jansen, J. D. 2005. Targeting education: The politics of performance and the prospects of 'Education for All'. International Journal of Educational Development, 25(4), 368-380. doi:10.1016/j.ijedudev.2005.04.009

Jessop, B. 2004. "Critical semiotic analysis and cultural political economy.” Critical discourse studies, 1(2): 159-174. doi: 10.1080/17405900410001674506

Jørgensen, M. W., and L.J. Phillips. 2002. Discourse analysis as theory and method. London: Sage.

King, K. 2014. China's Higher Education Engagement with Africa: A Different Partnership and Cooperation Model?. In Carbonnier, G.; M. Carton and K. King, eds. 2014. Education, Learning, Training: Critical Issues for Development, 151-173. Boston: Brill-Nijhoff.

Larner, W. 2000. “Neo-liberalism: Policy, ideology, governmentality.” Studies in political economy, 63: 5-25. http://spe.library.utoronto.ca/index.php/spe/article/download/6724/3723

Leckie-Tarry, H. 1995. Language and Context: A Functional Theory of Register (D. Birch, ed.). London: Pinter.

Martin, J.R. 1989. Factual Writing: exploring and challenging social reality. $2^{\text {nd }}$ ed. Oxford: Oxford University Press.

Moisio, J. 2014. Understanding the significance of EU higher education policy coopera-tion in Finnish higher education policy. Acta Electronica Universitatis Tamperensis : 1493.

Tampere: Tampere University Press. http://urn.fi/URN:ISBN:978-951-44-9657-8 
Mulderrig, J. 2011. "Manufacturing Consent: A corpus-based critical discourse analysis of New Labour's educational governance.” Educational Philosophy and Theory, 43(6): 562-578. doi: 10.1111/j.1469-5812.2010.00723.x

Muntigl, P. 2002. "Policy, politics and social control: a systemic functional linguistic analysis of EU employment policy?” Text 22(3): 393-441. doi: 10.1515/text.2002.016

Nicoll, K., and R. Edwards. 2004. "Lifelong learning and the sultans of spin: policy as persuasion?” Journal of Education Policy, 19(1): 43-55.

doi: 10.1080/0268093042000182627

Nicoll, K., and R. Harrison. 2003. "Constructing the good teacher in higher education: the discursive work of standards”. Studies in Continuing Education, 25(1): 23-35.

doi: 10.1080/01580370309289

Nokkala, T. 2007. Constructing the Ideal University-The internationalisation of higher education in the competitive knowledge society. Tampere: Tampere University Press. http://urn.fi/urn:isbn:978-951-44-7173-5

Nokkala, T., Forthcoming 2015. "National stories, convergent trends and divergent paths: discursive construction of Higher Education and Knowledge Society - nexus in higher education policy texts of five knowledge societies”. In Hoffman, D., and J. Välimaa, eds. Forthcoming 2015. Change in Networks, Higher Education and Knowledge Societies. Dordrecht: Springer.

Nokkala, T and J. Bacevic. 2014. "University autonomy, agenda setting and the construction of agency - The case of European University Association in the European Higher Education Area." European Educational Research Journal, 13(6): 699-714. doi: 10.2304/eerj.2014.13.6.699

Peters, M. 1996. Poststructuralism, politics and education. Westport, CT: Bergin \& Garvey

Robertson, S.L. 2005. "Re-imagining and rescripting the future of education: global knowledge economy discourses and the challenge to education systems." Comparative Education, 41(2): 151-170 doi: 10.1080/03050060500150922

Rose, N., and P. Miller. 1992. "Political power beyond the state: problematics of government.” British journal of sociology 43(2): 173-205. doi: 10.2307/591464

Saarinen, T. 2008. "Persuasive presuppositions in OECD and EU higher education policy documents.” Discourse Studies 10(3): 341-359. doi: 10.1177/1461445608089915

Saarinen, T. and J. Välimaa, 2012. "Change as an Intellectual Device and as an Object of Research.” In: Stensaker, B., J. Välimaa, and C. Sarrico, eds. 2012. Managing Reform in 
Universities: The Dynamics of Culture, Identity and Organisational Change, 41-61. Basingstoke: Palgrave Macmillan.

Sanderson, I. 2002. "Evaluation, Policy Learning and Evidence-Based Policy Making.” Public Administration, 80(1): 1-22. doi: 10.1111/1467-9299.00292

Schmidt, V.A. 2002. "Does Discourse matter in the politics of welfare state adjustment?" Comparative Political Studies, 35(2): 168-193. doi: 10.1177/0010414002035002002

Sell, S. and A. Prakash. 2004. "Using Ideas Strategically: The Contest Between Business and NGO Networks in Intellectual Property Rights.” International Studies Quarterly, 48(1):143175. doi: 10.1111/j.0020-8833.2004.00295.x

Suspitsyna, T. (2010). Accountability in American education as a rhetoric and a technology of governmentality. Journal of Education Policy, 25(5), 567-586.

doi: 10.1080/02680930903548411

Suspitsyna, T. 2012. "Higher education for economic advancement and engaged citizenship: An analysis of the US Department of Education Discourse.” The Journal of Higher Education, 83(1): 49-72. doi: 10.1353/jhe.2012.0003

Trowler, P. 2001. "Captured by the discourse? The socially constitutive power of new higher education discourse in the UK.” Organization, 8(2): 183-201.

doi: 10.1177/1350508401082005

Vaira, M. 2004. "Globalization and higher education organizational change: A framework for analysis.” Higher education, 48(4), 483-510. doi: 10.1023/B:HIGH.0000046711.31908.e5

Appendix: Selection of data (All links were correct 27.4.2015)

\section{Finland}

- MINEDU (1999). Education, training and Research in the information Society. A National Stategy for 2000-2004. Information society strategy 2000-2004. http://www.minedu.fi/OPM/Julkaisut/1999/liitteet/englishU/index.html (FI9)

- $\operatorname{TTN}(2008)$ Linjaus 2008. http://www.minedu.fi/export/sites/default/OPM/Tiede/tutkimus_ja_innovaationeuvosto/julkaisut/liitteet/Linjaus2008.pdf (FI23) 


\section{German}

- BMBF. 1999. "Information Society Germany - "Innovation and Jobs in the Information Society of the 21st Century”.” (DE2)

- BMBF 2000. Report of the Federal Government on Research 2000. (DE3)

- BMBF. 2002. "Innovation Policy - More Dynamic for Competitive Jobs.” http://www.cnel.gov.pt/document/innovation_policy_more_dynamic_for_compet_jobs .pdf (DE6)

\section{Portugal}

- Technological Plan. A growth strategy based on Knowledge, Technology and Innovation. Presentation Document. (2006).

http://www.inovasyon.org/pdf/Portugal.TechnologicalPlan.PresentationDocument.pdf (PT4)

\section{United Kingdom}

- The learning age. A renaissance for a new Britain. Green paper. (1998) http://www.lifelonglearning.co.uk/greenpaper/index.htm (UK2)

- The future of Higher Education. White paper. (2003) http://webarchive.nationalarchives.gov.uk/20121212135622/http://www.bis.gov.uk/as sets/biscore/corporate/migratedd/publications/f/future_of_he.pdf (UK3)

- $21^{\text {st }}$ Century Skills. Realising our potential. White Paper.(2003) http://webarchive.nationalarchives.gov.uk/20141006151154/http://www.apprenticeshi ps.org.uk/ /media/AAN/Documents/Research_1_100.ashx (UK4)

- World Class Skills: implementing the Leitch Review of Skills in England (2007) http://webarchive.nationalarchives.gov.uk/20130401151715/http://www.education.gov .uk/publications/eOrderingDownload/World-Class-Skills.pdf (UK6)

- Innovation Nation. White paper. (2008) http://webarchive.nationalarchives.gov.uk/20121106160710/http://www.bis.gov.uk/as sets/biscore/corporate/migratedD/ec_group/18-08-C_b (UK7) 


\section{United States}

\section{Federal level}

- United States Department for Education. 1997. Strategic Plan 1998-2002 http://www2.ed.gov/pubs/StratPln/intro.html (US1)

\section{California}

- The Master Plan Renewed. Unity, equity, quality and efficiency in California postsecondary education. Commission for the Review of the Master Plan for Higher Education. 1987. http://content.cdlib.org/ark:/13030/hb538nb32g/(US/CA1) 